\title{
EFFECT OF SALACIA OBLONGA ROOT EXTRACT AGAINST CLINICAL ISOLATES STAPHYLOCOCCUS AUREUS
}

\author{
ANANTHULA MOUNIKA ${ }^{1}$, BHARGAVI POKALA ${ }^{2}$, ZAHOORULLAH S MD. ${ }^{3}$, ANJANEYULU MUSINI ${ }^{1 *}$ \\ ${ }^{1}$ Centre for Biotechnology, Institute of Science and Technology, Jawaharlal Nehru Technological University, Hyderabad, Telangana, India. \\ ${ }^{2}$ Equine Veterinary Medical Centre, Qatar Foundation, Education City, Doha, Qatar. ${ }^{3}$ Atal Incubation Centre, Aleap Wehub, Aleap Industrial \\ Estate, Hyderabad, Telangana, India. Email: anjigen@gmail.com \\ Received: 02 November 2019, Revised and Accepted: 25 November 2019
}

ABSTRACT

Objective: Salacia oblonga Wall. is an important medicinal plant belonging to the family Celastraceae. The study reports the effect of S. oblonga root extracts against clinical isolate Staphylococcus aureus.

Methods: Antibacterial activity was evaluated by agar diffusion method and assay for minimum inhibitory concentration (MIC) of extract. Further, the effect of $S$. oblonga extract determined by DNA fragmentation and respiratory dehydrogenase enzyme activity assays.

Results: S. oblonga ethyl acetate root extract was evaluated for antibacterial activity towards clinical isolate $S$. aureus. Bacterial growth was determined in treated and control cells. Extract displayed good growth inhibition and MIC of the extract was $80 \mu \mathrm{g} / \mathrm{ml}$. DNA fragmentation assay was carried out, this result has shown that treated bacterial cell has DNA damage compared to the control cell. Further, respiratory dehydrogenase enzyme activity was determined. In the treated cells, enzyme activity was low compared to the control cells.

Conclusion: Salacia oblonga root extract inhibiting the growth of $S$. aureus by different modes of action.

Keywords: Clinical isolate, Staphylococcus aureus, DNA fragmentation assay, Respiratory dehydrogenase, Salacia oblonga.

(C) 2020 The Authors. Published by Innovare Academic Sciences Pvt Ltd. This is an open access article under the CC BY license (http://creativecommons. org/licenses/by/4. 0/) DOI: http://dx.doi.org/10.22159/ajpcr.2020.v13i1.36245

\section{INTRODUCTION}

Antimicrobial compounds are very important in reducing the worldwide burden of infectious diseases [1]. However, multidrug-resistant bacteria have become a significant public health risk and sometimes available antimicrobial agents are not effective toward infection caused by pathogenic bacteria. This has led to the search of new antibacterial compounds. From the past many years, plants have been used to treat infectious diseases and are considered as major source of new antimicrobial agents [2,3]. Numerous works have been done to study the antimicrobial effects of herbal plant extracts, including roots, stem, leaves, or flowers $[4,5]$. Many countries in the world have continued to encourage screening programs of plants used in traditional medicine and identification of their mode of action is important to authenticate their antimicrobial activities and possible inclusion in primary health care.

Salacia oblonga is an important medicinal plant that has been extensively used in traditional Indian Ayurvedic medicine as a liver tonic, anti-inflammatory agent, anodyne amenorrhea, diabetes, and treatment of wounds. The root bark extracts are used for itches, asthma, thirst, and ear diseases [6,7]. The important phytoconstituents of $S$. oblonga include salacinol, mangiferin, and kotanlol, with proven biological activities, namely, nephroprotection, antimutagenic, anti-inflammatory, and antimicrobial $[6,8,9]$. The present study was undertaken to evaluate the effect of antibacterial activity of $S$. oblonga root extracts against clinical isolate Staphylococcus aureus.

\section{METHODS}

\section{Chemical and reagents}

The analytical and high-performance liquid chromatography grade chemicals and reagents used in the study were procured from HiMedia and Merck. Amikacin antibiotic was obtained from Sigma-Aldrich (USA).
Culture collection

The clinical isolates of the human pathogen $S$. aureus collected from NICE Hospital, Mehdipatnam, Hyderabad, India, cultured in the laboratory by making use of the nutrient agar and activated in Luria Bertani (LB) broth at $37^{\circ} \mathrm{C}$ for $20 \mathrm{~h}$ before the experiment. For every fortnight, the culture was subjected to subculturing to maintain the pure cultures and stored glycerol stocks at a temperature of $-90^{\circ} \mathrm{C}$.

\section{Plant extract preparation}

Plants were collected from Western Ghats, Karnataka, India, and authenticated by Dr. N. Siddamallayya, Research Officer, Regional Research Institute, Bengaluru, India, as S. oblonga Wall. (RRCBI 7881). The plant was divided into aerial and root parts, washed properly, shade dried, and crushed to fine powder with the electric blender. The solvent used for the extraction was ethyl acetate (EtOAc). One hundred grams of dried root powder were used for extraction with the help of a Soxhlet apparatus and concentrated using a rotary evaporator (IKA RV 10) at $45^{\circ} \mathrm{C}$. The extract was stored at $4^{\circ} \mathrm{C}$ for further use.

\section{Antibacterial assay}

The antimicrobial activity of plant extract was examined by agar well diffusion method [10]. The Mueller-Hinton agar (MHA) was poured onto the Petri plates with an inoculum size of $10^{6}$ colony-forming unit (cfu)/ml of bacteria. The wells were prepared in the MHA plates with the help of a borer. Concentration of the extract $1 \mathrm{mg} / \mathrm{ml}$ was used for evaluating the antibacterial activity. A standard broad-spectrum antibiotic, amikacin $(50 \mu \mathrm{g} / \mathrm{ml})$ was used as a positive control, while the solvent served as negative control. The culture plates were incubated overnight at $37^{\circ} \mathrm{C}$ for allowing bacterial growth. After incubation, the antibacterial activity evaluated by observing zones of inhibition around the wells and measured. All the experiments were performed in triplicate. 


\section{DNA fragmentation assay}

DNA fragmentation experiment was done using standard DNA isolation procedure. Inoculate the culture into the $\mathrm{LB}$ broth incubated at $37^{\circ} \mathrm{C}$ overnight. Culture was centrifuged at $10,000 \mathrm{rpm}$ for $10 \mathrm{~min}$ and dissolved the pellet in the tris-ethylenediaminetetraacetic acid (EDTA) buffer. Added lysozyme $(10 \mathrm{mg} / \mathrm{ml}$ ) enzyme and $10 \%$ sodium dodecyl sulfate to the above suspension and kept it for the incubator at $37^{\circ} \mathrm{C}$ for $10 \mathrm{~min}$. Added RNase $(5 \mathrm{mg} / \mathrm{ml})$ and proteinase $\mathrm{K}(5 \mathrm{mg} / \mathrm{ml})$ of $5 \mu$ to the above suspension and incubate at $55^{\circ} \mathrm{C}$ water bath for $1 \mathrm{~h}$. Added equal volume of phenol-chloroform to the above suspension then gently vertex and tubes were centrifuge at 10,000 rpm for $5 \mathrm{~min}$. Transferred top aqueous layer into the fresh Eppendorf repeated this step twice. To this added $100 \mu \mathrm{l}$ of $3 \mathrm{M}$ sodium acetate and added $0.1 \mathrm{ml}$ volume chilled ethanol kept at $-20^{\circ} \mathrm{C}$ for $30 \mathrm{~min}$. To the pellet added $75 \%$ ethanol and kept at $20^{\circ} \mathrm{C}$ for $10 \mathrm{~min}$. Centrifuge the above suspension at $10,000 \mathrm{rpm}$ for $10 \mathrm{~min}$ and dry the pellet. Dissolve the pellet in tris-EDTA buffer. Isolated DNA was resolved on 1\% agarose in gel electrophoresis.

Effect of extract on enzymatic activity of respiratory chain dehydrogenases in S. aureus

Minimum inhibitory concentration (MIC) of extract was treated to the bacterial cells and incubated to $48 \mathrm{~h}$. Experiment was conducted in the absence of the extract as the control. Cultures were grown at $37^{\circ} \mathrm{C}$ with shaking at $200 \mathrm{rpm}$. One milliliter culture was sampled separately from the cultures and centrifuged at $12,000 \mathrm{rpm}$; then, the supernatants were discarded and the bacteria washed by phosphate-buffered saline (PBS) twice and added $0.9 \mathrm{ml}$ PBS to suspend the bacteria [11]. INT solution $(0.1 \mathrm{ml} 0.5 \%)$ was added, the culture was incubated at $37^{\circ} \mathrm{C}$ in dark for $2 \mathrm{~h}$, and then $50 \mu \mathrm{l}$ formaldehyde was added to terminate the reaction. Centrifuged the culture to collect the bacteria, and $250 \mu \mathrm{l}$ solutions of acetone and ethanol 1:1 in volume were used to distill the iodonitrotetrazolium formazan twice. The supernatants were finally combined. The dehydrogenase activity was then calculated according to the maximum spectrophotometrical absorbance of INF at $490 \mathrm{~nm}$ by spectrophotometer (Ultraviolet [UV]-2450 UV-visible spectrophotometer SHIMADZU).

\section{RESULTS}

\section{Antibacterial assay}

In the present study, the antibacterial activity of $S$. oblonga EtOAc root extract $(1 \mathrm{mg} / \mathrm{ml}$ ) against clinical isolate $S$. aureus was evaluated by agar well diffusion method. The extract has shown significant growth inhibition towards pathogen (Fig. 1)

\section{Growth of $S$. aureus exposed to $S$. oblonga extract}

The growth curves of $S$. aureus treated with root extract are shown in Fig. 2 by measuring optical density at $540 \mathrm{~nm}$. Under the absence of extract, $S$. aureus reached exponential phase rapidly. Then the culture was treated with $20,40,60$ and $80 \mu \mathrm{g} / \mathrm{ml}$ of extract, bacterial cells were lagged at different time point with 20,40 and $60 \mu \mathrm{g} / \mathrm{ml}$ concentrations. When the concentration of extract was $80 \mu \mathrm{g} / \mathrm{ml}$, no growth of $S$. aureus could be detected within 3 days (Fig. 2), indicating that MIC of extract to clinical isolate pathogen $S$. aureus was $80 \mu \mathrm{g} / \mathrm{ml}$.

\section{DNA fragmentation assay}

DNA fragmentation assay was done, to check the effect of S. oblonga extract against clinical isolate $S$. aureus DNA. Treated the pathogen with MIC concentration of the extract and resolved on 1\% agarose gel (Fig. 3). We have seen smear and fragmented in the treated DNA sample; on the other hand, no fragmentation was observed in control cells without treatment of the extract. This indicated our extract is acting on DNA and inducing the damage that leads to cell death of the pathogen.

Effect of $S$. oblonga extract on respiratory chain dehydrogenase of S. aureus

The effect of extract on respiratory chain dehydrogenase of $S$. aureus is shown in Fig. 4. Activity of respiratory chain dehydrogenase in control cells increased slightly with the incubation time. Interestingly, enzyme activity was decreased in treated cells with MIC concentration at $24 \mathrm{~h}$.

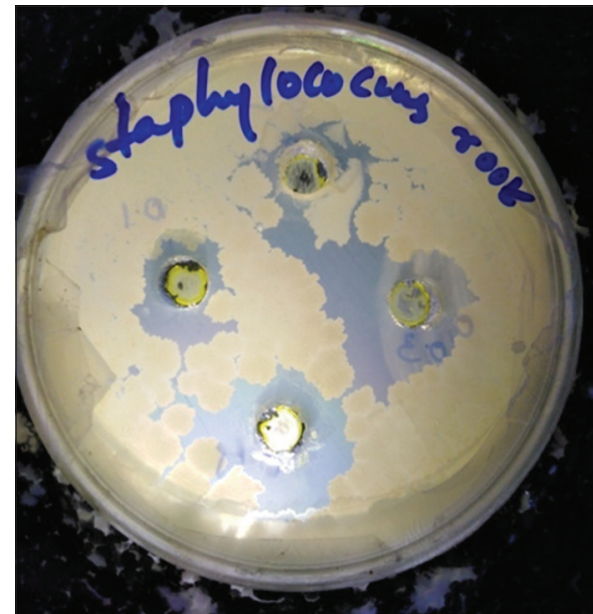

Fig. 1: Antibacterial activity of Salacia oblonga root extract against pathogen by agar diffusion method

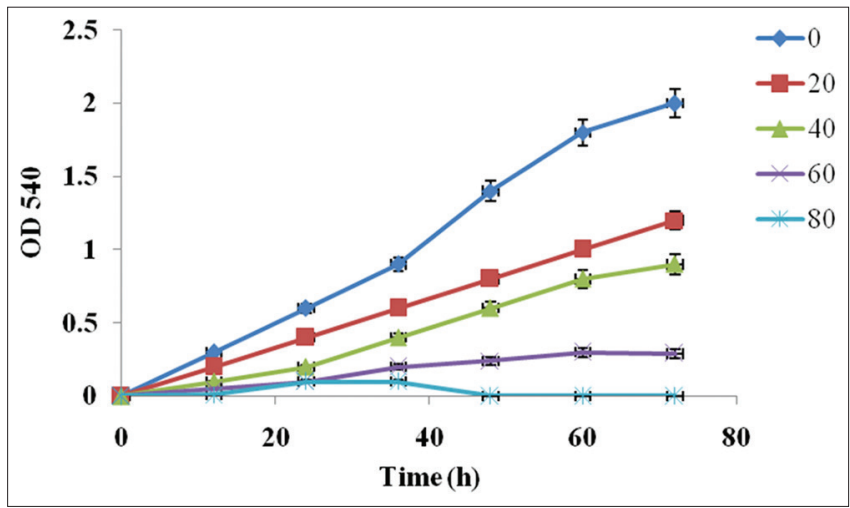

Fig. 2: Growth curve of Staphylococcus aureus exposed to different concentrations of Salacia oblonga extract

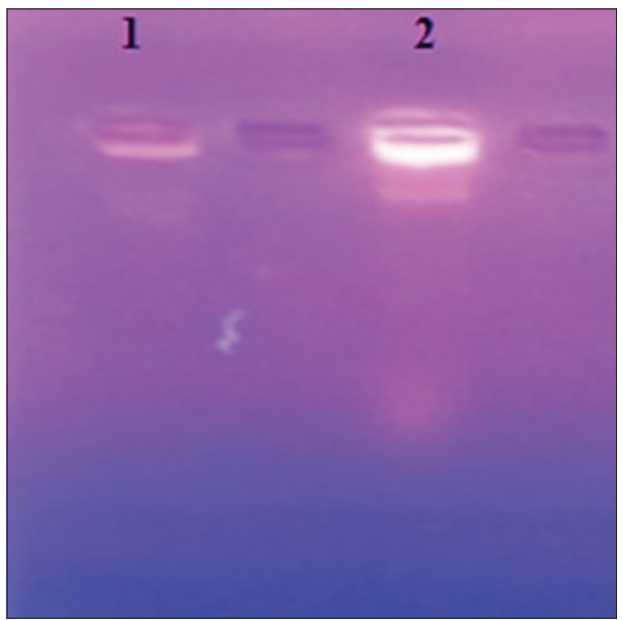

Fig. 3: Effect of Salacia oblonga extract by DNA fragmentation assay, (1) control, (2) treated

The results indicated that the activity of respiratory chain dehydrogenase of $S$. aureus could be inhibited by the $S$. oblonga root extract.

\section{DISCUSSION}

The search for novel antimicrobial became the major goal of various research groups oriented toward medicinal chemistry and pharmacology $[12,13]$. In the present study, S. oblonga root extract has 


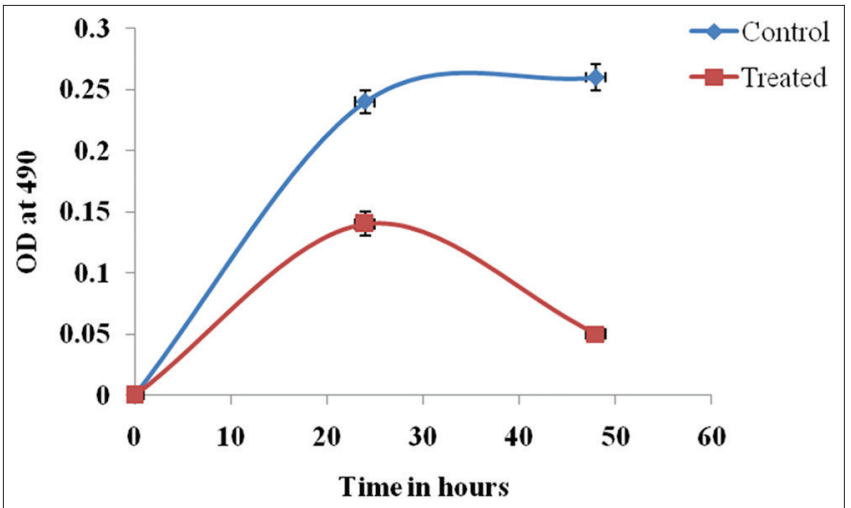

Fig. 4: Effect of Salacia oblonga extract on respiration chain dehydrogenase in Staphylococcus aureus cells. (Error bars represent the standard deviation of triplicate incubations)

displayed good antibacterial activity by agar diffusion method against clinical isolate $S$. aureus. Further, bacterial growth was determined by treating the extract at different concentrations and identified that the MIC concentration was $80 \mu \mathrm{g} / \mathrm{ml}$. To evaluate the effect of extract on DNA, fragmentation assay was carried out. DNA fragmentation was observed in treated cells with MIC concentration of the extract compared with the control cells without the treatment of extract. Caesalpinia coriaria ethanolic extract induces DNA fragmentation toward different pathogenic bacteria [14]. Our S. oblonga root extract also induces DNA damage in clinical isolates $S$. aureus. Hence, the $S$. oblonga root extract has shown antibacterial potential. Respiratory chain dehydrogenase enzyme activity was determined in treated and control cells. Enzyme activity was less compared to the control cells. Diterpene isolated from the medicinal plant Pseudognaphalium cheiranthifolium inhibited the bacterial respiratory chain enzyme and displayed antibacterial activity [15]. Phytochemicals from the crude extract of S. oblonga may break on cell wall and destroy respiratory chain dehydrogenase, further inhibiting respiration of cells. Phytochemicals present in the crude extract of $S$. oblonga might be inhibited the dehydrogenase enzyme activity and shown antibacterial activity.

\section{CONCLUSION}

S. oblonga root extract displayed good growth inhibition against clinical isolate $S$. aureus, this was confirmed by the agar diffusion method and growth of the bacteria after treatment with extract. The extract was inducing DNA damage and also inhibiting the respiratory chain dehydrogenase enzyme activity. Phytochemicals from the crude extract might be showing different modes of action and inhibiting the growth of the pathogen.

\section{AUTHORS' CONTRIBUTIONS}

Dr. Musini and Dr. Zahoorullah, both are designed the work, involved in the experiments and writing the manuscript. Other two authors involved in the experimental work.

\section{CONFLICTS OF INTEREST}

The authors have no conflicts of interest.

\section{REFERENCES}

1. Bhatia R, Narain JP. The growing challenge of antimicrobial resistance in the South-East Asia Region-are we losing the battle? Indian J Med Res 2010;132:482-6.

2. Boucher HW, Talbot GH, Bradley JS, Edwards JE, Gilbert D, Rice LB, et al. Bad bugs, no drugs: No ESKAPE! An update from the infectious diseases society of America. Clin Infect Dis 2009;48:1-2.

3. Giamarellou H. Multidrug-resistant gram-negative Bacteria: How to treat and for how long. Int J Antimicrob Agents 2010;36:50-4.

4. Oguntibeju OO. Antidiabetic, anti-inflammatory, antibacterial, antihelminthic, antioxidant and nutritional potential of musa paradisiacal. Asian J Pharm Clin Res 2019;12:19-3.

5. Amulkars S, Tale V, Khilari S, Pawar J. Antibacterial and antibiofilm activity of Quercus Infectoria galls on Rothia Dentocariosa isolated from dental caries. Asian J Pharm Clin Res 2019;12:159-62.

6. Chawla A, Singh S, Sharma AK. Salacia oblonga wall: A review on its pharmacognostic, phytochemical and pharmacological aspects. Int $\mathbf{J}$ Res Pharm Biomed Sci 2013;4:1215-28.

7. Li Y, Huang TH, Yamahara J. Salacia root, a unique ayurvedic medicine, meets multiple targets in diabetes and obesity. Life Sci 2008;82:1045-9.

8. Ismail TS, Gopalakrishnan $\mathrm{S}$, Begum $\mathrm{VH}$, Elango V. Anti-inflammatory activity of Salacia oblonga wall. And Azima tetracantha Lam. J Ethnopharmacol 1997;56:145-52

9. Musini A, Rao JP, Giri A. Isolation of potential antimicrobial compounds from Salacia oblonga Wall and their synergistic effect on human pathogens. J Microbiol Biotech Food Sci 2015;5:7-11.

10. Perez CP, Bazerque PM. An antibiotic assay by the well agar method. Acta Biol Med Exp 1990;15:113-5.

11. Li WR, Xie XB, Shi QS, Zeng HY, Ou-Yang YS, Chen YB. Antibacterial activity and mechanism of silver nanoparticles on Escherichia coli Appl Microbiol Biotechnol 2010;85:1115-22.

12. Radulović NS, Dekić MS, Stojanović-Radić ZZ, Zoranić SK. Geranium macrorrhizum L. (Geraniaceae) essential oil: A potent agent against Bacillus subtilis. Chem Biodivers 2010;7:2783-800.

13. van Vuuren S, Viljoen A. Plant-based antimicrobial studies--methods and approaches to study the interaction between natural products. Planta Med 2011;77:1168-82.

14. Anandhi D, Srinivasan PT, Kumar P, Jagatheesh S. DNA fragmentation induced by the glycosides and flavonoids from $C$. Coriaria. Int J Curr Microbiol App Sci 2014;3:666-73.

15. Tapia L, Torres J, Mendoza L, Urzúa A, Ferreira J, Pavani M, et al. Effect of 13-epi-sclareol on the bacterial respiratory chain. Planta Med 2004;70:1058-63. 